\title{
Toluene Emissions from Plants
}

\author{
A. C. Heiden, ${ }^{1}$ K. Kobel,${ }^{1}$ M. Komenda,${ }^{2}$ R. Koppmann, ${ }^{2}$ M. Shao ${ }^{1,3}$ \\ and J. Wildt ${ }^{1}$
}

\begin{abstract}
The emission of toluene from different plants was observed in continuously stirred tank reactors and in field measurements. For plants growing without stress, emission rates were low and ranged from the detection limit up to $2 \cdot 10^{-16} \mathrm{~mol} \cdot \mathrm{cm}^{-2} \cdot \mathrm{s}^{-1}$. Under conditions of stress, the emission rates exceeded $10^{-14} \mathrm{~mol} \cdot \mathrm{cm}^{-2} \cdot \mathrm{s}^{-1}$. Exposure of sunflower (Helianthus annuus L. cv. Gigantheus) to ${ }^{13} \mathrm{CO}_{2}$ resulted in ${ }^{13} \mathrm{C}$-labeling of the emitted toluene on a time scale of hours. Although no biochemical pathway for the production of toluene is known, these results indicate that toluene is synthesized by the plants. The emission rates of toluene from sunflower are dependent on nutrient supply and wounding. Since $\alpha$-pinene emission rates are also influenced by these factors, toluene and $\alpha$-pinene emissions show a high correlation. During pathogen attack on Scots pines (Pinus sylvestris L.) significant toluene emissions were observed. In this case emissions of toluene and $\alpha$-pinene also show a good correlation. Toluene emissions were also found in field experiments with pines using branch enclosures.
\end{abstract}

\section{Introduction}

Toluene often is the most abundant aromatic compound observed in urban atmospheres with mixing ratios up to several $10 \mathrm{ppb}$ [Atlas et al., 1994 and references therein]. Despite its reactivity, toluene is also observed in the marine troposphere at mixing ratios of some $10 \mathrm{ppt}$ in the Northern Hemisphere and below $10 \mathrm{ppt}$ in the Southern Hemisphere [Penkett, 1982; Nutmagual et al., 1985]. As all aromatic compounds, toluene in the continental troposphere is produced primarily from anthropogenic sources. Biomass burning is another source for toluene especially in the southern hemisphere [Koppmann et al., 1997].

Plants produce a large number of VOC, such as isoprene, mono- and sesquiterpenes as well as oxygenated compounds [e.g. Fehsenfeld et al., 1992]. Toluene emissions from plants have not been reported. Here we present results which show that toluene is emitted from sunflower and pine.

\section{Experimental}

VOC emissions were studied in a continuously stirred tank reactor ( $1000 \mathrm{~L}$ volume). The chamber contained 1 to 4 plants which were either grown in a nutrient solution

\footnotetext{
${ }^{1}$ Institut für Chemie der Belasteten Atmosphäre (ICG-2), Forschungszentrum Jülich, D-52425 Jülich, Germany.

${ }^{2}$ Institut für Atmosphärische Chemie (ICG-3), Forschungszentrum Jülich, D-52425 Jülich, Germany.

${ }^{3}$ Visiting scientist from Institute for Environmental Sciences, University of Beijing, PR China.
}

Copyright 1999 by the American Geophysical Union.

Paper number 1999GL900220.

0094-8276/99/1999GL900220\$05.00 (e.g. sunflower) or in soil. For emission studies we used sunflower (Helianthus annuus L. cv. Gigantheus) as a model plant because they are a fast growing plant species showing high emissions of several monoterpenes. In addition, experiments with pine (Pinus sylvestris L.) were conducted. The 3 to 4 years old pines were dug out from the Hartheimer Wald (Southern Germany). Only shoots and leaves of the plants were placed into the chamber by shielding the nutrient solution or the soil with a PTFE plate tightly closing around the plants' stems. The plants were illuminated with Osram HQI $400 \mathrm{~W} / \mathrm{D}$ lamps at a photosynthetic active radiation (PAR) of about $450 \mu \mathrm{E} \cdot \mathrm{m}^{-2} \cdot \mathrm{s}^{-1}$ at mid canopy height.

Ambient air was purified by an adsorptive drying device (Zander, KEA 70, Ecosorb) and subsequently passed over a heated $\mathrm{Pd} / \mathrm{Al}_{2} \mathrm{O}_{3}$-catalyst at $450^{\circ} \mathrm{C}$ to reduce the VOC concentrations at chamber inlet below the detection limit. Hundred L-min ${ }^{-1}$ were flushed through the chambers. Only during ${ }^{13} \mathrm{CO}_{2}$ exposure experiments (>95 atom\% ${ }^{13} \mathrm{C}$ ) the air flow was reduced to $20 \mathrm{~L} \cdot \mathrm{min}^{-1}$. Then, the chambers were flushed with synthetic air and ${ }^{13} \mathrm{CO}_{2}$ was added.

VOC emissions were determined by measuring concentrations of individual compounds at chamber inlet and outlet. Preconcentration was performed on solid adsorbents (Tenax TA/Carbotrap). A thermal desorption system (Gerstel Online-TDS G) connected to a cooled injection system (Gerstel CIS 3) was used. Subsequently, the substances were thermally desorbed into a GC-MS-system (HP5890 Series II - HP5972A). A detailed description of the GC/MS device can be found in Heiden et al. [1999].

Possible wall losses were investigated by adding the standard gas atmosphere from a permeation source to the air at the inlet of the empty chambers. No significant losses were found and thus, wall losses were neglected. Emission rates were calculated according to:

$$
\Phi_{V O C}=\frac{F_{a t r}}{A_{L}} \cdot\left([V O C]_{o u t}-[V O C]_{2 n}\right)
$$

$F_{a i r}$ is the air flow through the chamber, $A_{L}$ is the leaf area of the plants, $[\mathrm{VOC}]_{\text {out }}$ and $[\mathrm{VOC}]_{\text {in }}$ are the concentrations of individual VOCs measured at chamber outlet and inlet, respectively.

Field experiments were performed at Hartheimer Wald with 40 years old Pinus sylvestris L. using a branch enclosure with a volume of $35 \mathrm{~L}$. Air temperature, relative humidity and PAR were measured inside the bag using an HTR-1 probe (PP Systems). The air flow through the enclosure was $10 \mathrm{~L} \cdot \mathrm{min}^{-1}$. The inlet air was purified by a $\mathrm{Pd} / \mathrm{Al}_{2} \mathrm{O}_{3}-$ catalyst at $450^{\circ} \mathrm{C}$ and subsequently dried. Part of the outlet air flow was sucked through a glass tube containing Tenax TA and Carbotrap, with a flow rate of $100 \mathrm{~mL} \cdot \mathrm{min}^{-1}$ for $60 \mathrm{~min}$. A detailed description of the enclosure system used for the field experiments can be found in Parusel [1996], the analytical system is described by Wedel et al. [1998].

Identification was based on mass spectra and retention times of pure chemicals (Fluka/Aldrich, purity > 93\%). 


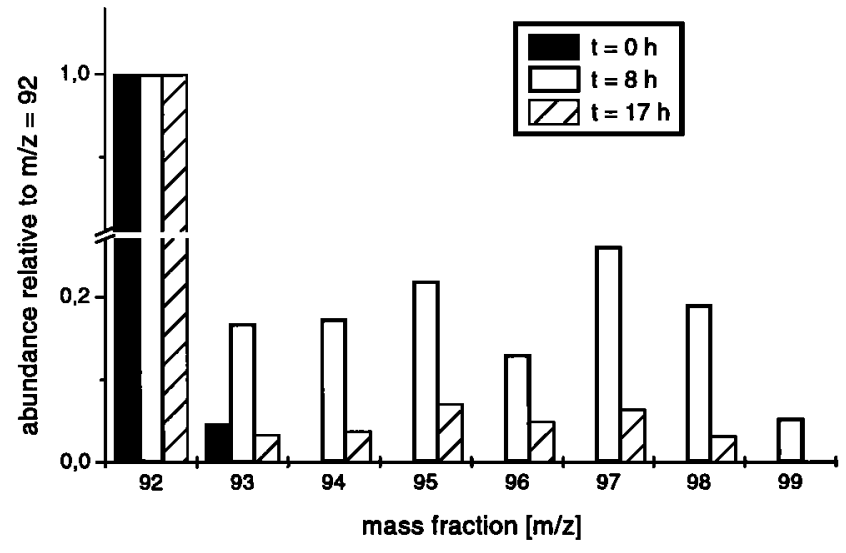

Figure 1. Relative abundance of $m / z=92$ to 99 in toluene emitted from sunflower before $(t=0 h)$, during $(t=8 \mathrm{~h}$ under illumination) and in darkness after ${ }^{13} \mathrm{CO}_{2}$ exposure $(\mathrm{t}=17$ h).

Data analysis was performed by integration of target ion peaks in the extracted ion mode or using an FID. The GC systems were calibrated using different permeation/diffusion sources containing pure chemicals in individual vials. A detailed description of the permeation and diffusion sources can be found in Schuh et al. [1997] and Gautrois and Koppmann [1999], respectively.

\section{Results}

\section{Laboratory Experiments}

For both investigated plant species typical emissions of monoterpenes and sesquiterpenes were observed. The results of these measurements will be described elsewhere. Also emissions of toluene were found.

To confirm that toluene is not formed as an artifact in our chamber, the air of the empty chamber was measured. Formation of toluene from compounds emitted from the plants was excluded by measuring these compounds in the air from the calibration system. In neither case toluene was found. The field measurements were conducted using a different analytical system. These results confirmed that toluene was not produced artificially.

Toluene Emission from Sunflower During exposure of a sunflower with ${ }^{13} \mathrm{CO}_{2}$ (8 $\mathrm{h}$ under illumination), the emitted toluene was found to be labeled with ${ }^{13} \mathrm{C}$ atoms. Figure 1 shows the relative abundance of the $\mathrm{m} / \mathrm{z}$ fractions: 92 to 99 for toluene as found before, during, and after ${ }^{13} \mathrm{CO}_{2-}$ exposure. The occurrence of peaks with masses +1 to +7 above $\mathrm{m} / \mathrm{z}=92$ (molar mass of toluene $=92 \mathrm{amu}$ ) shows clearly that all $7 \mathrm{C}$-atoms are labeled. At the end of the illumination period the exposure was stopped and air including $\mathrm{CO}_{2}$ with natural abundance of ${ }^{13} \mathrm{C}$ was used.

To test the factors that control the toluene emissions from sunflower, the nitrogen supply of the sunflower was changed and the plant was wounded. Four days after ${ }^{13} \mathrm{CO}_{2}$ exposure, the nitrate containing nutrient solution $\left(\left[\mathrm{NO}_{3}^{-}\right]=\right.$ $750 \mu \mathrm{M}$ ) was replaced by a solution of the same composition except of nitrate $\left(\left[\mathrm{NO}_{3}^{-}\right]=0 \mu \mathrm{M}\right)$. The nitrogen deficiency led to an increase of the emission rates of many VOC including toluene (see figure 2). Eleven days later the sunflower was wounded by cutting off a leaf $(<5 \%$ of the total leaf area). This wounding again led to an increase of the emission rates, including toluene emission. Two days after this experiment, nitrate was replenished to the nutrient solution $\left(\left[\mathrm{NO}_{3}^{-}\right]=750 \mu \mathrm{M}\right)$. Thereafter, toluene emission rates remained at a constant level.

Figure 2 also shows a significant diurnal variation of the toluene emissions. During daytime $\left(\mathrm{PAR}=450 \mu \mathrm{E} \cdot \mathrm{m}^{-2} \cdot \mathrm{s}^{-1}\right.$, $\mathrm{T}=23{ }^{\circ} \mathrm{C}$ ) the emission rates are about a factor of 2 larger than during darkness $\left(\mathrm{T}=19.5^{\circ} \mathrm{C}\right)$. Caused by the nitrogen deficiency, the toluene emission rates increased from $\approx 1 \cdot 10^{-15}$ to $2 \cdot 10^{-15} \mathrm{~mol} \cdot \mathrm{cm}^{-2} \cdot \mathrm{s}^{-1}\left(10^{-15} \mathrm{~mol}\right.$ toluene $\cdot \mathrm{cm}^{-2} \cdot \mathrm{s}^{-1}=89 \mathrm{ng} \cdot \mathrm{g}(\mathrm{dw})^{-1} \cdot \mathrm{h}^{-1}$ for sunflower). Wounding led to an increase to $1.3 \cdot 10^{-14} \mathrm{~mol} \cdot \mathrm{cm}^{-2} \cdot \mathrm{s}^{-1}$. The emission rates of $\alpha$-pinene showed a similar behavior and a significant correlation between the emissions of toluene and $\alpha$-pinene was found $\left(r^{2}=0.91, n=554\right)$.

Figure 3 shows the labeling of toluene for a time period of about $80 \mathrm{~h}$ during this experiment. Labeling occurs on a time scale of $12 \mathrm{~h}$ (fit to $1-\exp \left(-t / \tau_{\text {increase }}\right)$ ), decreases during the night, increases again the next day and thereafter decreases again on a time scale of $25 \pm 3 \mathrm{~h}$ (fit to $\left.\exp \left(-\mathrm{t} / \tau_{\text {decay }}\right)\right)$.

Toluene Emissions from Pine To find out if toluene is also emitted from coniferous plant species, the emissions from pine (4 plants together) were studied. Toluene emissions are low as long as the pines do not suffer from stress. During this experiment, about $1 \%$ of the needles became yellow within a time period of five days. This effect was probably caused by a pathogen attack, implied by the emissions of compounds produced during lipoxygenase activity [e.g. Heiden et al., 1999]. However, the pathogen attacking the plants was not identified. Obviously caused by the pathogen attack, the emission rates of all compounds increased about one order of magnitude. During this time a significant correlation between the emission rates of toluene and $\alpha$-pinene was found again, but the ratio between these emission rates (toluene/ $\alpha$-pinene $=0.5$ ) was different from that found for sunflower $(0.07)$.

In addition to toluene other aromatic compounds were emitted from pines as a reaction to pathogen attack. Among those was methyl salicylate, which is produced in the shikimate pathway [e.g. Yalpani et al, , 1993]. The correlation between the emission rates of toluene and methyl salicylate was much less significant $\left(r^{2}<0.3\right)$ than the correlation between the emission rates of toluene and $\alpha$-pinene.

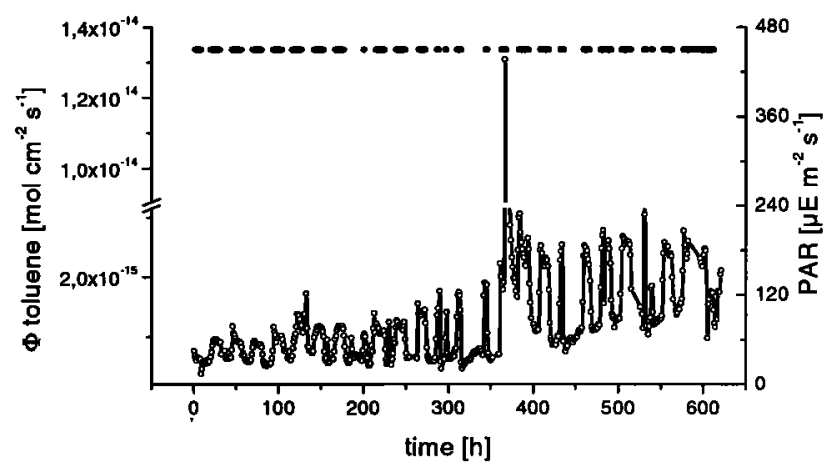

Figure 2. Time sequence of toluene emissions from sunflower. ${ }^{13} \mathrm{CO}_{2}$ exposure: $t=0-8 \mathrm{~h}$, removal of nitrate: $t=100$ $h$, wounding: $t=364 \mathrm{~h}$, replenishment of nitrate: $t=420 \mathrm{~h}$. Bars show PAR, right scale. 


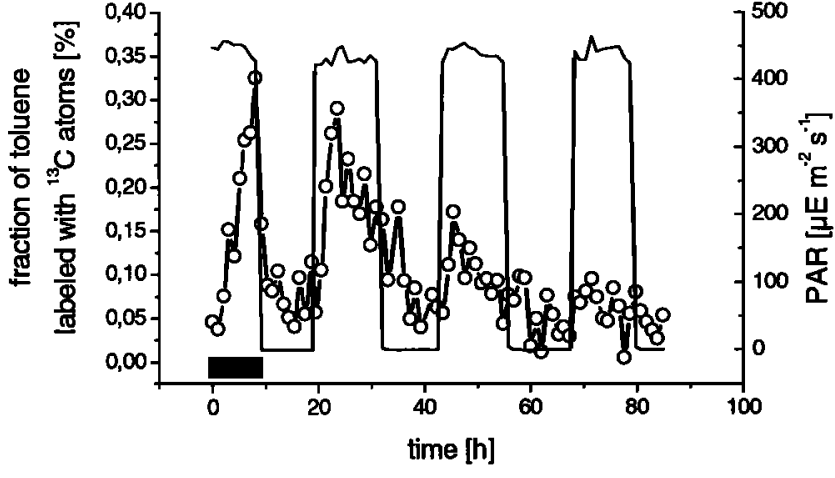

Figure 3. Time sequence of ${ }^{13} \mathrm{C}$-labeling in toluene. Labeling is calculated for the sum of ${ }^{13} \mathrm{C}$-atoms in the emitted toluene. PAR is indicated by the line, ${ }^{13} \mathrm{CO}_{2}$ exposure time is indicated by the black bar.

The pines were also exposed to ${ }^{13} \mathrm{CO}_{2}(8 \mathrm{~h}$ under illumination). Again, labeling of toluene was observed, but the amount of labeling $(<3 \%)$ was much lower than that observed for the sunflower. Under pathogen attack, the emission rates of all compounds did not show the significant diurnal variation as observed before. It seemed that pools were opened and the compounds were just evaporating from these storage pools.

After finishing the measurements with the living plants, some green and yellow needles were taken and introduced into flasks flushed with synthetic air. A head space analysis showed that the abundance of toluene relative to that of $\alpha$-pinene was 0.5 for yellow and 0.05 for green needles.

\section{Field Experiments}

In addition to the laboratory studies, 4 measurement campaigns were conducted between April and October with pine at Hartheimer Wald. In all experiments, toluene emissions were observed. The emission rates ranged from the detection limit up to $2 \cdot 10^{-16} \mathrm{~mol} \cdot \mathrm{cm}^{-2} \cdot \mathrm{s}^{-1}\left(10^{-15} \mathrm{~mol}\right.$ toluene $\cdot \mathrm{cm}^{-2} \cdot \mathrm{s}^{-1}=13 \mathrm{ng} \cdot \mathrm{g}(\mathrm{dw})^{-1} \cdot \mathrm{h}^{-1}$ for pine), much lower than found for the plants in the laboratory under stress. A diurnal variation was observed (Figure 4). In April, when pines came into leaf, emissions of all VOC including those of toluene were higher than those found in the other experiments. During the other campaigns toluene emissions were low and data were highly scattered. This might explain that a significant correlation between the emission rates of toluene and $\alpha$-pinene was found only during the campaign in April $\left(\mathrm{r}^{2}=0.74, \mathrm{n}=36 ; \mathrm{r}^{2}=0.10\right.$, $\mathbf{n}=53 ; \mathbf{r}^{2}=0.14, \mathbf{n}=48$, and $\mathbf{r}^{2}=0.07, \mathbf{n}=53$ for the measurements in April, July, September, and October).

\section{Discussion}

The results of our experiments, especially the labeling of toluene with ${ }^{13} \mathrm{C}$ after exposure to ${ }^{13} \mathrm{CO}_{2}$ show that toluene is synthesized by the plants. However, the biosynthetic pathway of toluene production is far from being understood. It is known that aromatic compounds are produced by plants within the shikimate pathway. Our experiments give no hint to a coupling between the emission rates of such compounds and toluene. Hence, it seems unlikely that toluene is produced within the shikimate pathway. It is also known that aromatic compounds can be produced from monoterpenes within the plants [e.g. Hess, 1988]. The significant correlation between toluene and $\alpha$-pinene emissions suggests that toluene may be produced within the mevalonate pathway. However, we have no proof for this hypothesis yet.

The time dependence of labeling implies that toluene is produced from a substrate with a turnover time of about 12 h. The decay occurs on a time scale twice as long. Furthermore, the amount of labeling during night is significantly smaller than during daytime.

Schuh et al. [1997] argue that monoterpene emissions from plants occur from two processes: Emissions in parallel to biosynthesis (only daytime) and emissions from pools (day- and nighttime). On the one hand, the results of the labeling experiments show that toluene is synthesized and emitted in parallel to biosynthesis. On the other hand, the large increase of toluene emissions caused by wounding of sunflower implies that pools may have been opened. The results of the experiments with green and yellow needles also imply that there are pools for toluene in plants. Thus, in analogy, we conclude that toluene emissions also occur from pools as well as in parallel to biosynthesis.

On time scales of several days there is a good correlation between the emission rates of toluene and $\alpha$-pinene. Ratios of toluene emission rates relative to those of $\alpha$-pinene are different for pines under pathogen attack and sunflower under nitrogen deficiency and wounding. With respect to the emissions from pine the relationship changed $\left(0.005, \mathrm{r}^{2}=0.8, \mathrm{n}\right.$ $=224$ before, $0.15, \mathrm{r}^{2}=0.86, \mathrm{n}=10$ at the beginning, and $0.5, \mathrm{r}^{2}=0.9, \mathrm{n}=48$ during pathogen attack). Hence, the ratio of these emissions also changes with the physiological state of the plant. Therefore, the ratios measured between the emissions of toluene and $\alpha$-pinene cannot be used to estimate concentrations of toluene from this natural source in remote areas.

For plants without stress the emissions are relatively low. But, for plants suffering from stress as pathogen attack, nitrogen deficiency or wounding, the emission rates may be high. In such cases there may be non negligible intrusion of natural emitted toluene. Toluene, benzene or the ratio of the concentrations of these compounds are often used as tracers for polluted air masses [e.g. Gelencser et al., 1997].

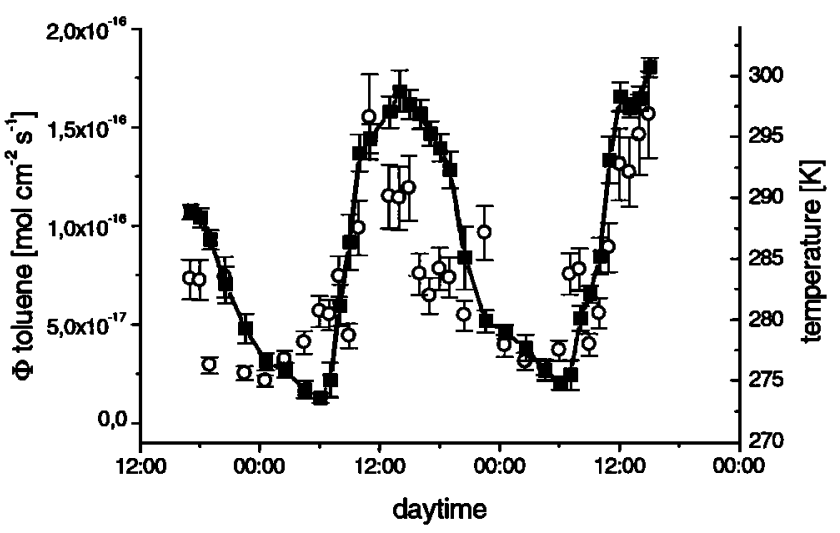

Figure 4. Diurnal variation of toluene emissions measured using the branch enclosure (left scale, circles). Right scale, squares: Temperature, the bars represent the variation of temperature during sampling time. 
If toluene is emitted from biogenic sources, misleading results may be obtained.

Acknowledgments. This work was financially supported by the German Ministry for Education, Science, Research and Technology within the Tropospheric Research Program (grant No. 07TFS23/07TFS24). J. W. thanks Fonds der Chemischen Industrie for financial assistance.

\section{References}

Atlas, E. L., S. M. Li, L. J. Standley, and R. A. Hites, Natural and Anthropogenic Organic Compounds in the Global Atmosphere, in Global Atmosphernc Change, edited by C. N. Hewitt and W. T. Sturges, pp. 313-381, Chapman and Hall, London, 1994.

Fehsenfeld, F., J. Calvert, R. Fall, P. Goldan, A. B. Guenther, C. N. Hewitt, B. Lamb, S. Liu, M. Trainer, H. Westberg, and P. Zimmerman, Emissions of volatile organic compounds from vegetation and the implications for atmospheric chemistry, Global Biogeochem. Cycles 6, 389-430, 1992.

Gautrois, M., and R. Koppmann, Diffusion technique for the production of gas standards for measurements of volatile organic compounds at atmospheric concentrations, submitted to J. Chrom. A, 1999.

Geiencser, A., K. Siszler, and J. Hlavay, Toluene-Benzene Concentration Ratio as a Tool for Characterizing the Distance from Vehicular Emission Sources, Environ. Sci. Technol. 31, 2869$2872,1997$.

Heiden, A. C., T. Hoffmann, J. Kahl, D. Kley, D. Klockow, C. Langebartels, H. Mehlhorn, H. Sandermann Jr., M. Schraudner, G. Schuh, and J. Wildt, Emission of volatile organic compounds from ozone-exposed plants, accepted for publication, Ecol. Appl., 1999.

Hess, D., Pflanzenphysiologie, 8th Edition, p. 221, UTB, Stuttgart, ISBN 3-8001-2569-2, 1988.

Koppmann, R., A. Khedim, J. Rudolph, D. Poppe, G. Helas, M. Welling, T. Zenker, M. O. Andreae, Emissions of organic trace gases from savanna fires in southern Africa during SAFARI 92 and their impact on the formation of tropospheric ozone, $J$. Geophys. Res. 102, 18879-18888, 1997.

Nutmagual, W., and D. R. Cronn, Determination of selected aromatic hydrocarbons at remote continental and oceanic locations using photoionization/flame-ionization detection, J. Atmos. Chem. 2, 415-433, 1985.

Parusel, E., Zur Bedeutung der Pflanzen als Quelle leichter Nicht-Methan-Kohlenwasserstoffe für die Atmosphäre, Landbauforschung Völkerode, Sonderheft 167, Bundesforschungsanstalt für Landwirtschaft, Braunschweig-Völkerode, ISSN 0376$0723,1996$.

Penkett, S. A., Nonmethane organics in the remote troposphere, in Atmospheric Chemistry, edited by E. D. Goldberg, pp. 329355, Springer-Verlag, New York, 1982.

Schuh, G., A. C. Heiden, T. Hoffmann, J. Kahl, J. Rudolph, and $\mathrm{J}$. Wildt, Emission of volatile organic compounds from sunflower and beech: Dependence on temperature and light intensity, J. Atm. Chem. 27, 291-318, 1997.

Wedel A., K. P. Múller, M. Ratte, and J. Rudolph, Measurements of volatile organic compounds (VOC) during POPCORN 1994: Applying a new on-line GC-MS-technique J. Atmos. Chem 31, 73-103, 1998.

Yalpani, N., J. León, M. A. Lawton, and I. Raskin, Pathway of Salicylic Acid Biosynthesis in Healthy and Virus-Inoculated Tobarco, Plant Physiology 103, 315-321, 1993.

A. C. Heiden, K. Kobel, J. Wildt, Institut für Chemie der Belasteten Atmosphäre (ICG-2), Forschungszentrum Jülich, D52425 Jülich, Germany.

M. Komenda, R. Koppmann, Institut für Atmosphärische Chemie (ICG-3), Forschungszentrum Jülich, D-52425 Jülich, Germany.

M. Shao, Institute for Environmental Sciences, University of Beijing, PR China.

(Received December 28, 1998; revised February 12, 1999; accepted February 22, 1999.) 